\title{
LEGAL AND ORGANIZATIONAL SPECIFICITIES OF THE EUROPEAN UNION'S OFFICE FOR HARMONIZATION IN THE INTERNAL MARKET
}

The creation of the Community trademark (CTM) in 1993 was a true revolution in legal and economic terms. Given the supranational legal nature of this newly created trademark, it had to be followed by the establishment of a new agency of the European Union: the Office for Harmonization in the Internal Market (OHIM). Notwithstanding the fact that the EU has a remarkable network of various bodies, offices and other entities, the legal status of the newly created Office is not easily comparable with the majority of other agencies at the European level. The international success of the CTM, as well as the legal originality and the economic importance of the OHIM justify the study of its normative and organizational specificities. To this end, this paper will first focus on the legal basis and the practical consequences of Office's institutional position (Chapter 1 - OHIM as an autonomous institutional structure), before entering, in a second stage, in some legal aspects of its internal organization (Chapter 2 - Competencies of the OHIM's bodies).

Key words: Office for harmonization in the internal market, trademark law, European Union agencies, European Union law, community trademark

Uroš Ćemalović, PhD, Assistant Professor, Faculty of Law, Public Administration and Security, Megatrend University, Belgrade, e-mail: ucemalovic@megatrend.edu.rs 


\section{Introduction}

The Community trademark (CTM $)^{1}$ is created in 1993 , in order to ensure the possibility ${ }^{2}$ of supranational and unique protection of this aspect of the intellectual property in the European Union (EU) ${ }^{3}$. Even though some other international organizations, like the World Intellectual Property Organization (WIPO), can assure the international protection ${ }^{4}$ of various intellectual property rights, the CTM was the first truly supranational trademark, with unique effects in all EU's Member States, established with the purpose to create legal conditions "which enable undertakings to adapt their activities to the scale of the Community, whether in manufacturing and distributing goods or in providing services" ${ }^{\prime}$. This new legal, economic and political reality has also required the introduction of a new institutional and procedural framework, whose function is to ensure that the obtaining of CTMs is centralized, with uniform protection and supranational effects. The Office for Harmonization in the Internal Market $(\mathrm{OHIM})^{6}$ is created to ensure the accomplishment of this complex and origi-

The Council Regulation (EC) No 40/94 of 20 December 1993, as well as the Council Regulation (EC) No 207/2009 of 26 February 2009 are referring to "Community trade mark" and not "trademark". However, due to its widespread presence in theory, in this article will be used the second term. See also: Dinwoodie B. Graeme, Janis D. Mark: Trademark Law and Theory - A Handbook of Contemporary Research, Edward Elgar Publishing Limited, Cheltenham 2008; Brookman L. Adam: Trademark Law - Protection, Enforcement and Licensing, Wolters Kluwer, New York 2014; Beebe Barton: "The Semiotic Analysis of Trademark Law”, University of California Law Review 51/2003, 621-640; Bartholomew Mark: "Advertising and the Transformation of Trademark Law", New Mexico Law Review 38/2008, 1-48; Hu H. Robert: "International Legal Protection of Trademarks in China", Marquette Intellectual Property Law Review 1/2009, 71-99.

2 Of course, the national trademarks and national institutions for their protection continued to co-exists with the CTM.

3 Notwithstanding the fact that, according to the Lisbon Treaty (2009), the European Community (EC) has ceased to exist and was replaced by the European Union, in this article it will also be referred to the EC and European Economic Community (EEC). The reason for this choice lies in the progressive establishment of the Common/Internal/Unique Market and in the need to present the background for the creation of the CTM and the OHIM.

4 The protection of a Trade mark through WIPO is international only by its mean of obtaining, but remains fully national by its legal nature: several national trademarks are obtained by one international demand.

5 Recital 1 of the Council Regulation (EC) No 40/94 of 20 December 1993 on the Community trademark, replaced by the recital 2 of the Council Regulation (EC) No 207/2009 of 26 February 2009. For the purposes of this article, all the quotations will be based on the Regulation (EC) No 207/2009, while it will be referred to the Regulation (EC) No 40/94 only when it is necessary to explain certain historical aspects of the OHIM's functioning.

6 It is interesting to note that the Council Regulation (EC) No 40/94 of 20 December 1993, as well as the Council Regulation (EC) No 207/2009 of 26 February 2009 are referring to "harmonisation" in OHIM's name, while OHIM in all its official documents uses the 
nal mission. Even if the OHIM is not an international organization, in various aspects in can be compared with certain regional or international organizations having competencies in the field of the intellectual property, like the WIPO, or the European Patent Organization. In order to put some more light on the specificity of the OHIM as an agency of the EU, it is first necessary to analyze the legal basis and the practical consequences of its institutional position (Chapter 1 - OHIM as an autonomous institutional structure), before entering, in a second stage, in some legal details of its internal organization (Chapter 2 - Competencies of the OHIM's bodies). Since the status of its staff is more closely linked to the issue of the legal status of the Office as such, this issue will be treated in the first chapter.

\section{OHIM as an autonomous institutional structure}

The administrative procedure for trademark registration by the national authorities and its validity only in the context of an internal legal order imposed geographical limits to the protection: the right conferred by a national trademark is always a territorial monopoly. Therefore, the need to create and develop the legal mechanisms in order to ensure an international trademark protection became even more evident in the context of the principle of territoriality of industrial property rights. That is why the first international efforts, starting with the Paris Convention singed in March 1883, aimed at creating intergovernmental arrangements to facilitate the protection of trademarks in several states. The trademark has remained a territorial monopoly, but its international registration has become possible. In other words, for quite a long period, the economic necessity of the development of cross-border trade have not questioned the principle of territoriality. More than a century after the signature of the Paris Convention was conceived the first genuinely supranational intellectual property (IP) right: the Community trademark (CTM), created by the adoption of the Council Regulation (EC) No 40/94. Even if the establishment of the CTM was "the logical consequence of the European efforts in order to harmonize the national legislations"7, the newly created trademark was a true revolution in legal and economic terms.

The originality of the legal nature of IP rights is, in many aspects, similar to the uniqueness of the project of economic and political integration that was progressively established by the European Community/Union. Suffice is here to highlight three crucial elements: the innovative capacity that was needed for

term "harmonization"; see, for example http://pmd.oami.europa.eu.edgesuite.net/AnnualReport/FINAL/ohim/en/trademarks.html (15.10.2014.) In this article will be used the term "harmonization".

Gastinel Eric: La marque communautaire, LGDJ, Paris 1998, 7. 
their creation, the rapid evolution of both $\mathrm{EEC} / \mathrm{EC} / \mathrm{EU}^{8}$ and IP rights and, finally, the difficulties they may cause in terms of classification. On the one hand, every IP right shares all the basic characteristics of other property rights, but their object is immaterial, intangible. On the other hand, the European Union has become - throughout its numerous and profound changes that occurred during more than a half of century that elapsed between the adoption of the Treaty of Rome and the entry into force (2009) of the Lisbon Treaty - a political and legal entity sui generis, halfway between an international organization and a quasifederal structure that shares sovereignty with its Member States. When the EU started to make some important steps in IP regulation, all the solutions adopted had to be original and unprecedented. Therefore, the creation of the CTM had to be followed by the establishment of a new EU's institution: the Office for Harmonization in the Internal Market. This newly created body contributed to the phenomenon some authors named "the proliferation of the number of actors in what can be loosely termed the European administrative space" .

Like the majority of international organizations with significant competencies in the field of economy or international trade, the $\mathrm{EC}^{10}$ have had the power to create different entities whose function was to contribute to the achievement of its goals. Moreover, due to the fact that the European Court of Justice (after the adoption of the Lisbon Treaty: Court of Justice of the European Union) has progressively defined the fundamental principles of EC law, "the controversy over the determination of the legal nature of the Community legal system (...) largely faded"11. The EU now disposes of an impressive network of various bodies, offices and other entities, commonly referred to as "agencies", often having different legal status and responsibilities. However, their common point is that they are "set up to perform specific tasks under EU law"12. The EU agencies are grouped into four categories, which include decentralized agencies, executive agencies, EURATOM agencies and bodies and European Institute for Innovation and Technology. In October 2014, without taking into consideration the executive agencies and the agencies created to support the aims of the European Atomic Energy Community Treaty, their total number is 38 . These entities are

\section{See fotnote 2.}

9 Curtin Deirdre: „Holding (Quasi-)Autonomous EU Administrative Actors to Public Account", European Law Journal Vol. 13, 4/2007, 523.

$10 \quad$ Ibid.

11 Blumann Claude, Dubouis Louis: Droit institutionnel de l'Union européenne, Litec, Paris, 2008, 416.

12 Agencies and other EU bodies, official website of the EU, http://europa.eu/about-eu/agencies/index_en.htm (21.10.2014.) 
named as follows: agency ${ }^{13}$, body $y^{14}$, office ${ }^{15}$, authority ${ }^{16}$, centre ${ }^{17}$, foundation ${ }^{18}$, institute $^{19}$, college $^{20}$, board ${ }^{21}$ or unit ${ }^{22}$. In this complex institutional forest, the place of the OHIM seems to be guaranteed, despite the fact that it often lacks the visibility. As it was underlined (by quoting the December 2008 issue of European Voice) in the OHIM's Annual Report for the same year, "The Office for Harmonization in the Internal Market is not the best known of EU organizations, but it is arguably one of the most successful" ${ }^{23}$. In addition, in the President's introduction, opening the OHIM's Annual Report for 2013, Antonio Campinos stressed that "the Office made progress in a number of areas in 2013, staying on track to meet the objectives set out in the Strategic Plan for 2011-2015"24. This progress is, among other reasons, certainly due to the quality of the legal structure introduced by the Regulation on the Community trademark; defining the OHIM as an EU agency can only be a starting point in the study of its legal specificity.

13 Like, for example, the Agency for the Cooperation of Energy Regulators, the European Agency for Safety and Health at Work or the European Aviation Safety Agency. In total, there are $14 \mathrm{EU}$ agencies that officially bear this name.

14 Only one name of an EU agency includes this term: the Body of European Regulators for Electronic Communications.

15 Besides the OHIM, there are four other offices: the Community Plant Variety Office, the European Asylum Support Office, the European Police Office and European Public Prosecutor's Office, still in preparation.

16 There are four "authorities" among EU agencies: the European Banking Authority, the European Food Safety Authority, the European Insurance and Occupational Pensions Authority and the European Securities and Markets Authority.

17 Among all EU agencies, there are four "centres": the European Centre for Disease Prevention and Control, the European Centre for the Development of Vocational Training, the European Monitoring Centre for Drugs and Drug Addiction and the Translation Centre for the Bodies of the European Union.

18 There are two EU agencies whose names include this term: the European Foundation for the Improvement of Living and Working Conditions and the European Training Foundation.

19 The European Institute for Gender Equality.

20 The European Police College.

21 The Single Resolution Board, still in preparation.

22 The European Union's Judicial Cooperation Unit.

23 Official website of the OHIM, https://oami.europa.eu/ohimportal/en/annual-report (21.10.2014.)

24 Official website of the OHIM, Annual Report for the year 2013, President's Introduction, http://pmd.oami.europa.eu.edgesuite.net/Annual-Report/FINAL/ohim/en/introduction. html (21.10.2014.) 
Despite the relative brevity of its introductory remarks ${ }^{25}$, the Council Regulation (EC) No 207/2009 of 26 February 2009 on the Community trademark ${ }^{26}$ (hereinafter referred to as "Regulation") dedicated to the OHIM three of its nineteen recitals. In addition, the entire Title XII (Articles 115 to 144) is exclusively devoted to the administrative, financial and legal functioning of the agency of the European Union responsible for registering trademarks and designs. The reason for this approach is the fact that the new supranational industrial property right required the establishment of a body responsible for its transnational registration, with precise competencies and structured internal organization. Therefore, we will first analyze the general normative framework applicable to this unique body, before examining in detail the various aspects related to the legal status and the functioning of the OHIM. Starting from the observation that the new trademark requires administrative measures "for implementing (...) the trademark law created by this Regulation ${ }^{\text {“27 }}$, its $12^{\text {th }}$ recital specifies that "it is therefore essential, while retaining the Community's existing institutional structure and balance of powers, to provide for an Office for Harmonization in the Internal Market (trademarks and designs) which is independent in relation to technical matters and has legal, administrative and financial autonomy" ${ }^{28}$. As a result, a direct link between the new supranational IP right and the autonomous body responsible for its obtaining is already established. Furthermore, mentioning the new body in the context of the "Community's existing institutional structure and balance of powers" shows that the newly created Office will have the legal status not easily comparable with the majority of other agencies at the European level. In order to preserve its independence, the OHIM "should be a body of the Community having legal personality and exercising the implementing powers (...) and that it should operate within the framework of Community law without detracting from the competencies exercised by the Community institutions"29. This statement has a dual function: first, it announces the legal status of the Office, which will be developed in detail by the provisions of Articles 115 to 123 of the Regulation; secondly, it puts the OHIM in a larger European institutional

$25 \quad$ The Council Regulation (EC) No 207/2009 of 26 February 2009 has 19 recitals and 167 articles, devoting about $5 \%$ of the text to the introductory remarks. On the other hand, the Directive 2008/95/CE of the European Parliament and of the Council of 22 October 2008 to approximate the laws of the Member States relating to trade marks contains 14 recitals and 19 articles, dedicating approximately $20 \%$ of its text to the non-normative part.

26 Recital 1 of the Council Regulation (EC) No 207/2009 of 26 February 2009 specifies that, because "the Council Regulation (EC) No 40/94 of 20 December 1993 on the Community trade mark has been substantially amended several times (...) in the interests of clarity and rationality the said Regulation should be codified". See also footnote 4 .

27 Recital 12 of the Council Regulation (EC) No 207/2009.

28 Ibid.

29 Ibid. 
context, especially regarding the legal protection against its decisions, but also concerning the auditing of its accounts.

The Article 115 of the Regulation defines the Office as "a body of the Community" having the legal personality. Moreover, "in each of the Member States the Office shall enjoy the most extensive legal capacity accorded to legal persons under their laws; it may, in particular, acquire or dispose of movable and immovable property and may be a party to legal proceedings". It is interesting to note that, thus defined, the legal capacity of the OHIM is much greater than the legal capacity enjoyed by the European Union before the entry into force (December 1, 2009) of the Lisbon Treaty. As regards OHIM's contractual liability, it is "governed by the law applicable to the contract in question"30, while "in the case of non-contractual liability, the Office shall, in accordance with the general principles common to the laws of the Member States, make good any damage caused by its departments or by its servants in the performance of their duties $^{\prime 31}$. Given that, in the current state of the European Union's legal system, there is no unified EU contract law, the Regulation allows a wide application of the national legal provisions, without losing the intention to seek for their lowest common denominator.

Concerning the employees of the OHIM in a broad sense, their legal status is defined both by the rules of the Staff Regulations of officials of the European Union (for general issues, as specified by the Article 116 of the Regulation) and by certain special rules required by their independence and special skills. For example, the Article 136, paragraph 4 of the Regulation specifies that "the President of the Boards of Appeal and the chairmen and members of the Boards of Appeal (...) in their decisions (...) shall not be bound by any instructions", which means they are not supposed to seek or receive instructions from any authority or person, especially if it belongs to any Member State institution or body. In this respect, their status was, mutatis mutandis, comparable to that of members of the European Commission, for whom the ex-Article 213, paragraph 2 of the Treaty establishing the European Community ${ }^{32}$ specified that "in the performance of these duties, they shall neither seek nor take instructions from any government or from any other body". In addition, the members of the Boards of Appeal "may not be removed from office unless there are serious grounds for such removal and the Court of Justice, after the case has been referred to it by the Administrative Board on the recommendation of the President of the Boards of Appeal, after consulting the chairman of the Board to which the member con-

\footnotetext{
$30 \quad$ Article 118, paragraph 1 of the Council Regulation (EC) No 207/2009.

31 Article 118, paragraph 3 of the Council Regulation (EC) No 207/2009.

32 It is interesting to note that the Article 245 of the Treaty on the Functioning of the European Union considerably reformulated the provision of ex-Article 213. The level of independence is now formulated in more general terms, given that "Member States shall respect their independence and shall not seek to influence them in the performance of their tasks".
} 
cerned belongs, takes a decision to this effect"33. The role of the Court of Justice in the removal of certain OHIM officials clearly shows that the level of their independence is incommensurate with the position of the employees of other EU agencies.

In financial and organizational matters, the OHIM's independence is considerable, but it has certain limitations. The various decisions of its bodies those concerning the CTM registration process, as well as decisions relating to the establishment and implementation of the budget - are subject to judicial or financial control ${ }^{34}$. Consequently, the necessity "to ensure that parties who are affected by decisions made by the Office are protected by the law in a manner which is suited to the special character of trademark law" ${ }^{\prime 35}$ imposed the existence of "an appeal to lie from decisions of the examiners and of the various divisions of the Office" ${ }^{36}$. The first instance of appeal against those decisions is within OHIM itself - the Board of Appeal of the Office. Subsequently, the decisions of this Board are "amenable to actions before the Court of Justice (...) which has jurisdiction to annul or to alter the contested decision" 37 . Therefore, the EU law related to the CTM largely consists of the interpretation of the provisions of the Regulation by the Court of Justice, while the judicial role of the OHIM remains significant. With regard to the control of the OHIM's financial functioning, the EU legislature predicted, without naming or prioritizing them, three modalities of its verification. It is, however, clear that there is some degree of difference between them, especially because, "as far as is compatible with the particular nature of the Office, the financial provisions shall be based on the financial regulations adopted for other bodies set up by the Community" ${ }^{38}$. On the one hand, the internal element of the financial control is the creation of an audit function, placed under the authority of the President of the Office, whose mission is to undertake the technical and procedural execution of the OHIM's budget. On the other hand, the modalities for establishment and implementation of the budget are specified by the Budget Committee, Office's internal body, while the adoption of these rules is subject to the Commission's and the Court of Auditors' favorable opinion. The third level of the control - placed completely outside the institution itself - is the audit performed by the Court of Auditors, whose role is to examine the accounts of the Office's total revenue and expenditure. Even if the nature of this auditing makes OHIM comparable to any other

\footnotetext{
33 Article 136, paragraph 1 of the Council Regulation (EC) No 207/2009.

34 The judicial control is of particular importance for the existence of the Community trademark, given the fact that the interpretation of the Court of Justice of the EU contributes to the creation of unified EU trademark law.

35 Recital 13 of the Council Regulation (EC) No 207/2009.

$36 \quad$ Ibid.

$37 \quad$ Ibid.

38 Article 143 of the Council Regulation (EC) No 207/2009.
} 
EU agency, one major difference allows it to keep operational and functional autonomy: "an autonomous budget whose revenue comes principally from fees paid by the users of the system"39. The overall autonomy of the OHIM's institutional structure seems to be guaranteed by the normative context relative to the Community trademark, which remains, with more than 114.000 applications in $2013^{40}$, very popular in EU's business community. In the future, the institutional position of the Office will remain dependent of the success of EU's single market and its capacity to overcome the global economic crisis.

\section{Competencies of the OHIM's bodies}

Like any other EU's administrative entity having legal personality and operational autonomy, the OHIM has management structures globally comparable to those existing in other EU agencies. However, the specificity of its mission and the role it has in trademark registration make the Office comparable to the national authorities, existing in each of the $28 \mathrm{EU}$ Member States, competent for the IP protection. However, "initially hesitant, the European Union has gradually become interested in intellectual property and adopted a variety of legislative acts, which were subsequently supplemented by numerous decisions of the Court of Justice of the European Union" ${ }^{\text {s1 }}$, to the extent that EU law "has become the main source of influence on the national laws ${ }^{\text {'32 }}$. Consequently, the nature of the OHIM's bodies and their competencies will be analyzed without reference to the existing national authorities, given the fact that the CTM has supranational effects and that its registration is centralized. It is, therefore, first necessary to examine in detail the entities of the Office competent "for taking decisions in connection with the procedures laid down ${ }^{143}$ in the Council Regulation 207/2009; secondly, the attention should be paid to the OHIM's administrative bodies in a strict sense.

Article 130 of the Regulation sets out an exhaustive list of various existing entities or organs within the Office whose function is exclusively linked to the implementation of the procedures for registration of CTMs: examiners, Opposition Divisions, Administration of Trademarks and Legal Division, Cancellation Divisions and Boards of Appeal. However, the term "instance" could be used

\footnotetext{
$39 \quad$ Recital 18 of the Council Regulation (EC) No 207/2009.

40 Official website of the OHIM, Annual Report for the year 2013, Volumes - Trademarks, http://pmd.oami.europa.eu.edgesuite.net/Annual-Report/FINAL/ohim/en/trademarks. html (24.10.2014.)

41 Geiger Cristophe: Constructing European Intellectual Property - Achievements and New Perspectives, Edward Elgar Publishing Limited, Cheltenham, 2013, 5.

42 Ibid.

43 Article 130 of the Council Regulation (EC) No 207/2009.
} 
for the first entity mentioned by Article 130, for at least two reasons: "examiners" cannot be considered as a typical body or organ, given that this denomination is chosen for being the most appropriate in order to legally designate all the employees of the Office that have the same role and competencies in the implementation of registration procedures; secondly, examiners are also the first instance, in the strictly procedural sense, in the process that starts with CTM application and ends once all conditions for its registration are met. Moreover, the analysis of the Regulation's drafting technique related to the definition of examiners' prerogatives clearly shows that they have a general competence, given that they are "responsible for taking decisions on behalf of the Office (...) except in so far as an Opposition Division is responsible ${ }^{34}$. In other words, in the absence of an opposition, all the decisions taken in the context of the process starting with CTM application are made by the examiners, who are, in this case, the only entity within the Office to have participated in the process of the registration of this supranational trademark. As one important procedural provision specifies, "where an application meets the requirements of this Regulation and where no notice of opposition has been given within the period referred to in Article 41(1) or where opposition has been rejected by a definitive decision, the trade mark shall be registered as a Community trade mark" ${ }^{\prime 5}$. Therefore, the power in the hands of the examiners is considerable, which requires an efficient legal and organizational framework in order to ensure the effective appeal against their decisions.

Since the decisions in the context of examination of 1) the conditions for application and 2) the absolute grounds for refusal determine whether the CTM will be registered or not, the opportunity to appeal against them represents a guarantee of OHIM's fair and efficient functioning. Additionally, from the point of view of an economic operator wanting to register a CTM, it is also the most visible part of the OHIM's work, especially given the fact that after the filing of the CTM application, the examiner's decision represents the first contact of the user with the services of the Office. As it was emphasized in one of its Annual Reports, "maintaining quality in CTM and opposition decisions continued to be a major Office priority" 46 and, to this end "in recent years increased efforts have been made to ensure that the measurement and improvement of the quality of decisions is more systematic and transparent both within the Office and to the outside world ${ }^{247}$. However, the effectiveness of these efforts also depends on the rules intended to ensure the impartiality and the independence of the examiners. On the one hand, the position of an examiner is incompatible with

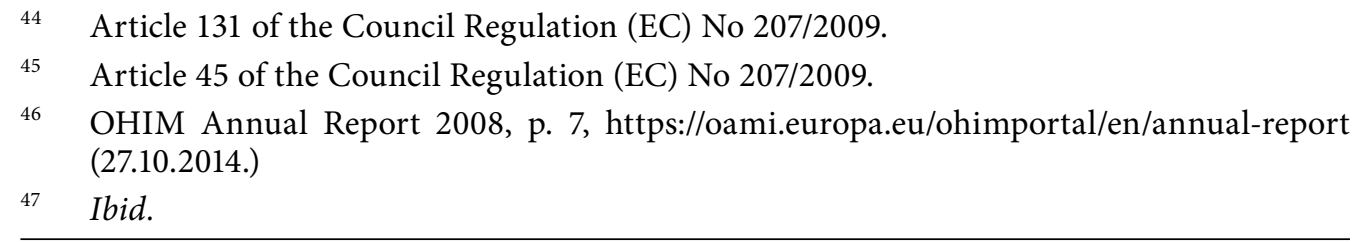


the exercise of other functions within the OHIM's decision-making bodies having a role in the CTM registration procedure; therefore, "the President of the Boards of Appeal and the chairmen and members of the Boards of Appeal may not be examiners" ${ }^{348}$. This rule ensures the independence of the Board members, but also reinforces, in an indirect way, the examiners' position, ensuring a different composition of the two bodies. On the other hand, the impartiality of the examiners is ensured by the provision specifying that they "may not take part in any proceedings if they have any personal interest therein, or if they have previously been involved as representatives of one of the parties"49. Moreover, the exclusion of an examiner may be requested only if suspected of partiality, but the objection "shall not be admissible if, while being aware of a reason for objection, the party has taken a procedural step" ${ }^{50}$. However, the nationality of the examiner may not be invoked as a ground for exclusion, even if she/he is a national of the same Member State as one of the parties. The status of OHIM staff generally requires the independence from all national governmental bodies, including those involving the State of which they are nationals. As Martin Groenleer rightly remarked, "cultivating a distinct loyalty to the organization (...) may serve as a means of shifting staff's loyalty to the supranational organization (instead of to their professional group or their national jurisdiction) and thus enhance the agency's autonomy"51. At the end of 2013, the OHIM had a total of 925 employees $^{52}$ with numerous different nationalities. An organization with such a linguistic and cultural richness of its staff cannot allow this diversity to be the victim of divergent national influences.

As for the other organs of the OHIM that can be involved in the process of CTM registration, Opposition and Cancellation Divisions and Boards of Appeal are among the most important for functioning of the Office as EU agency. In this context, every decision about the opposition to CTM application is made by the Opposition Division consisting of three members, of which at least one has to be a lawyer. Moreover, proceedings before the Division is not public, but its decisions are published. One of the greatest difficulties in the operation of the Office is the constant increase of the received oppositions and the accumulation of unsolved cases. As highlights OHIM's Annual Report for 2013, "the rate of oppositions against published CTMs has remained broadly stable over the past

\footnotetext{
$48 \quad$ Article 136, paragraph 5 of the Council Regulation (EC) No 207/2009.

49 Article 137, paragraph 1 of the Council Regulation (EC) No 207/2009.

$50 \quad$ Article 137, paragraph 3 of the Council Regulation (EC) No 207/2009.

51 Groenleer Martijn: The Autonomy of European Union Agencies - A Comparative Study of Institutional Development, Uitgeverij Eburon, Delft 2009, 50.

52 Official website of the OHIM, Annual Report for the year 2013, HR Reform and Finance, http://pmd.oami.europa.eu.edgesuite.net/Annual-Report/FINAL/ohim/en/introduction. html (27.10.2014.)
}

Vol. 11, No 4, 2014: 263-278 
three years at around $16-17 \%$, with just over 17000 filed during $2013^{\prime 53}$, while "opposition e-filing has continued to grow steadily, reaching $46 \%$ of the total" 54 . Accordingly, the Office has set up a research group specialized in opposition and one can only hope a significant reduction in the duration of the proceedings before this instance.

The Cancellation Divisions are responsible "for taking decisions in relation to an application for the revocation or declaration of invalidity" 55 of a CTM. Their composition and decision-making procedure and are subject to the rules similar to those applicable to the Opposition Divisions: they have three members (at least one should be a lawyer), while only "in certain specific cases provided for in the Implementing Regulation, the decisions shall be taken by a single member" (identical provisions of Articles 132 and 134 of the Regulation). It is important to note that during 2013 "cancellation requests rose to just under 1 400 , which is $10 \%$ more than the previous year" ${ }^{56}$, but "when measured against the total number of CTMs, cancellations have remained constant over recent years at less than $0.2 \%$ of the Register" 57 . This percentage shows that the number of cancelation request depends almost exclusively on the quantity of CTM applications. Moreover, the operators demanding the cancellation are often well prepared, allowing to the Office to have greater efficiency in decision-making. As regards the Administration of Trademarks and Legal Division, it primarily has a residual jurisdiction, given that it is "responsible for those decisions required by this Regulation which do not fall within the competence of an examiner, an Opposition Division or a Cancellation Division"58. Secondly, this Division is exclusively competent for decisions in respect of entries in the Register of CTMs and for keeping the list of professional representatives before the OHIM. Given the fact that the workload of this body is relatively small compared to that of the Opposition and Cancellation Divisions, there is only one Administration of Trademarks and Legal Division. In addition, the nature of its responsibilities allows that the decisions are taken by a single member.

Finally, the Board of Appeal is a joint instance of appeal against the decisions of four other OHIM's bodies involved in the CTM registration procedures. This Board can make decisions in one of three possible formations: the "classical"

53 Official website of the OHIM, Annual Report for the year 2013, Trademarks, http:// pmd.oami.europa.eu.edgesuite.net/Annual-Report/FINAL/ohim/en/trademarks.html (29.10.2014.)

$54 \quad$ Ibid.

55 Article 134, paragraph 1 of the Council Regulation (EC) No 207/2009.

56 Official website of the OHIM, Annual Report for the year 2013, Trademarks, http:// pmd.oami.europa.eu.edgesuite.net/Annual-Report/FINAL/ohim/en/trademarks.html (29.10.2014.)

57 Ibid.

58 Article 133, paragraph 1 of the Council Regulation (EC) No 207/2009. 
chamber of three members, enlarged or, exceptionally, single-member chamber, if the Board handling the case decides to confer it because of the "lack of difficulty of the legal or factual matters raised, the limited importance of the individual case or the absence of other specific circumstances ${ }^{159}$. Any party wishing to attack, before the EU's judicial authorities, the decision of an examiner or a Division, must first address to the Board of Appeal. Unlike most national courts, when the Court of Justice of the $\mathrm{EU}$ is competent for an appeal against a decision of OHIM's Board of Appeal, it may annul, but also alter the contested decision.

Despite the fact that - both in their mode of operation as well as concerning the rules governing their composition - all the bodies of the Office involved in the CTM registration process are supranational, the same conclusion, unfortunately, cannot be brought when it is about OHIM's administrative organs in a strict sense. Although its operational management is the responsibility of the President, the fact remains that it is appointed by the Council, which consists of one representative from each EU's Member State. However, the Council's somewhat inter-governmental modus operandi does not influence the inherently supranational mission of the Office, and that for at least two reasons: firstly, the OHIM's Administrative Board takes its decisions by a simple majority; secondly, its real influence on the functioning of other departments of OHIM is relatively low, while the effective management is in the hands of the director. An EU agency with growing efficiency and a Community trademark enjoying international popularity would hardly be imaginable without the strong component of supranational governance within the Office.

59 Article 135, paragraph 5 of the Council Regulation (EC) No 207/2009. 


\section{Literature}

- Bartholomew Mark (2008): "Advertising and the Transformation of Trademark Law", New Mexico Law Review 38/2008, 1-48

- Blumann Claude, Dubouis Louis (2008): Droit institutionnel de l'Union européenne, Litec, Paris

- Beebe Barton (2003): “The Semiotic Analysis of Trademark Law”, University of California Law Review 51/2003, 621-640

- Brookman L. Adam (2014): Trademark Law - Protection, Enforcement and Licensing, Wolters Kluwer, New York

- Curtin Deirdre (2007): „Holding (Quasi-)Autonomous EU Administrative Actors to Public Account”, European Law Journal Vol. 13, 4/2007, 523-541

- Dinwoodie B. Graeme, Janis D. Mark (2008): Trademark Law and Theory - A Handbook of Contemporary Research, Edward Elgar Publishing Limited, Cheltenham

- Gastinel Eric (1998): La marque communautaire, LGDJ, Paris

- Geiger Cristophe (2013): Constructing European Intellectual Property Achievements and New Perspectives, Edward Elgar Publishing Limited, Cheltenham

- Groenleer Martijn (2009): The Autonomy of European Union Agencies - A Comparative Study of Institutional Development, Uitgeverij Eburon, Delft

- Hu H. Robert (2009): “International Legal Protection of Trademarks in China”, Marquette Intellectual Property Law Review 1/2009, 71-99

- Agencies and other EU bodies, official website of the EU, http://europa.eu/ about-eu/agencies/index_en.htm (21.10.2014.)

- Official website of the OHIM, Annual Report for the year 2013, http:// pmd.oami.europa.eu.edgesuite.net/Annual-Report/FINAL/ohim/en/introduction. html (21.10.2014.)

Paper received: October $31^{\text {st }}, 2014$

Approved for publication: November $17^{\text {th }}, 2014$
Rad primljen: 31. oktobar 2014. Odobren za štampu: 17. novembar 2014. 


\section{Doc. dr Uroš Ćemalović,}

Fakultet za pravo, javnu upravu i bezbednost

Megatrend Univerzitet, Beograd

\section{PRAVNE I ORGANIZACIONE SPECIFIČNOSTI KANCELARIJE EVROPSKE UNIJE ZA HARMONIZACIJU NA UNUTRAŠNJEM TRŽIŠTU}

\section{S a ž e t a k}

Stvaranje komunitarnog žiga je predstavljalo istinsku revoluciju u pravnom i ekonomskom smislu. Imajući u vidu nadnacionalnu pravnu prirodu novostvorenog žiga, bilo je neophodno da njegov nastanak bude praćen uspostavljanjem nove agencije Evropske unije: Kancelarije za harmonizaciju na unutrašnjem tržištu (KHUT). Međutim, i pored činjenice da EU raspolaže značajnom mrežom različitih tela, centara i drugih organizacija, novostvorena Kancelarija ima pravni status koji nije lako uporediv sa većinom drugih agencija na nivou Unije. Međunarodni uspeh komunitarnog žiga, kao i pravna jedinstvenost i ekonomski značaj KHUT opravdavaju izučavanje njenih normativnih i organizacionih specifičnosti. Kako bi se odgovorilo tako postavljenom cilju, ovaj rad će se prvo posvetiti pravnoj osnovi i praktičnim posledicama institucionalnog položaja Kancelarije (poglavlje 1 - KHUT kao autonomna institucionalna struktura), da bi se potom usredsredio na pravne aspekte njene unutrašnje organizacije (poglavlje 2 - Nadležnosti tela u sastavu Kancelarije).

Ključne reči: kancelarija za harmonizaciju na unutrašnjem tržištu, žigovno pravo, agencije Evropske unije, pravo Evropske unije, komunitarni žig 
